\section{CHARACTERISTICS AND COMPETENCES OF A CONTEMPORARY POLISH MANAGER WORKING IN INTERNATIONAL MARKETS}

\author{
Beata Anna Glinkowska
}

\author{
University of Lodz \\ Faculty of Management, Lodz, Poland \\ e-mail: bettysue@uni.lodz.pl
}

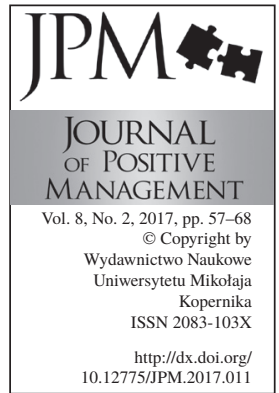

JOURNAL

OF POSITIVE

awnictwo Naukowe

Kopernika

http://dx.doi.org/

10.12775/JPM.2017.011

\begin{abstract}
Purpose: The main aim of the study is to identify the competences and characteristics of a contemporary Polish manager working in the international markets either directly or indirectly (in Polish enterprises) and then to compare that profile with that of the Polish manager proposed by J. Penc in 2001. There are many models of managerial competence, however, this model was chosen for several reasons:

- it is far enough in time but not so far to be drastically different;

- it is a model of early Polish market economy; currently the market shows symptoms of a mature economy, so both can be juxtaposed;

- it comprehensively covers "hard" and "soft" competences;

- shows the actual state of market in 2001 and the probabist state for 2010, which, in combination with current research, provides an overview of changes and directions of evolution;

- it is a model for a market economy that is intensively searching for its opportunities in connection with the globalization process of the economy.

Such an action is to bring the following results:

- the creation of a personal-competence profile of the contemporary Polish manager; Comparison and analysis of differences in the personal-competence profile over the past sixteen years;

- the ability to develop a characteristics and competencies profile of the manager of the future;

- the emergence of a Polish model, which will allow foreign researchers to have a basis for comparison with the existing (or emerging) models of managerial competencies from other countries.
\end{abstract}

The study is the result of empirical research and comparative studies.

Methodology/approach: Own empirical research has been conducted for the development of this study. The research instruments applied in this study was self-administered questionnaire and researcher-administered questionnaire. The study was conducted on a group of 90 managers from micro, small and medium enterprises in 2014-2017 (55 companies). These managers are experienced in international business. The companies they manage are co-operating with at least one foreign market for several years. This cooperation takes place in the following forms: import and export (direct and indirect), production cooperation of project cooperation, strategic alliance or direct foreign investment. The research organizations have a productive, commercial, service and project activity range. There are no virtual-only companies, even though some companies 
CHARACTERISTICS AND COMPETENCES

Beata Anna Glinkowska exhibit its features, as they also run wholesale web-based sales of their products. All the researched organizations are in contact with different cultures and diverse environments. An analysis of subject literature was carried out, both on retrospective and current works. A critical comparative analysis was performed.

Findings: This study is a comparative analysis of the managerial characteristics and competences profile of the Polish manager over the last sixteen years. The directions of evolving these qualities and competences in contemporary Polish managers have been identified, which may be the basis for future analyses. The conducted research has shown a clear evolution of the characteristics and competences of a modern manager in Polish conditions. Based on them, the future profile can be determined.

Implications/limitations: The study may be an inspiration for further research and analyses. It can also be used to build the personal - competence profile of a contemporary manager and manager of the past(at least in Polish terms), which can directly translate into the development (and creation) of managers' education in order to develop their competence. The created profile can be used to build job descriptions, and in the recruitment process of "right" managers for modern businesses. The philosophical differences of organizations operating on international markets and the cultural diversity of some (mainly non-European) countries may result in limiting the application of managerial personal - competence profile.

Originality/value: This article is an original work which contains an original project of the profile of the characteristics and competences of a contemporary "Polish international" manager, which can be successfully used in economic practice and scientific theory.

Keywords: organization, manager, manager-leader, manager profile, internationalization

Paper type: Research paper

\section{Introduction}

In recent years, the number of world-wide studies on the competences of modern manager (manager-leader) and of the manager (manager-leader) of the future. Despite the growing number of studies, this topic remains unverified (,on a hypothesis level") (Kuc, 2016). However, it is still important. The pace of change requires the development of new qualities and skills, and organizational management becomes a process saturated with creativity, continuous professional and personal development, and the pursuit of good relationships in the workplace and outside of it. Although management science does not explicitly define the concept of a manager, nor does it have a list of universal attributes and requirements for managers, the most common view on management sees it as a process of pursuit of success in every area of the organization. After an analysis of individual profiles of managerial competences, the focus of this paper was put on the profile of the managerial skills of the Polish manager, cited by J. Penc in 2001. This model was deliberately chosen due to its relative closeness in time (it was published 16 years ago), simplicity, and Polish background. Despite a mere 16 years of business-related history, there has been a noticeable increase in the internationalization of business activity of Polish businesses. More and more 
enterprises are directly or indirectly expanding their activity outside their home country (Glinkowska and Kaczmarek, 2016a). Many barriers, threats, but also opportunities for enterprises (Glinkowska and Kaczmarek, 2016b) result from this international action, which is the reason for the necessity of expanding the managerial competence by new, unknown or not yet applied competences, as well as lessening the importance of some values, held earlier in high regard.

Own research has proven the inspiration for writing this article. The research has been conducted in recent years on a sample of fifty-five Polish companies that are expanding or already have expanded (indirectly or directly) outside their home market. Enterprises are primarily (90\%) located in the Lodz Region (Central Poland) and represent different industries: manufacturing, service and trade. They cooperate with at least one foreign country. Size wise, they belong to the micro, medium and small businesses sector. The research instruments used were self-administered questionnaire and researcher-administered questionnaire. The interview technique also allowed for free expression of the respondents, who were middle and line managers, as well as specialists with different functions. When it came to small companies, primarily their owners were interviewed, who managed in an indivisible way the economic activity on the Polish and foreign markets. The sample selection was deliberately targeted and addressed to a total of ninety respondents who were experienced in contact with foreign markets(from few to several years).

The aim of this study was to identify the most desirable qualities and competences of the contemporary Polish manager. On the other hand, the aim of this article is to compare the obtained list of competences and features of the contemporary manager with J. Penc's profile of a Polish manager published 16 years ago (Penc, 2001). From these aims emerges a clear research task: an attempt to define the characteristics and competences profile of the Polish manager of the future. It has been hypothesized that the competences of the modern Polish manager (and future manager) are evolving in the direction of leadership.

\section{Managerial competences in the subject literature}

Having the authority of knowledge, professionalism, adaptability to change, problem solving ability, effectiveness in action, pragmatism, rationalism and firmness are according to P. F. Drucker the factors characterizing a manager (Kubik, 2012). Today, a manager is perceived primarily as a leader and high-end business professional, who who manages resources (including human resources), is responsible for talent search and management, and the strategic plan to bring the company to success (Austen, ,'Organization and Management" No. 4 (12). In the literature you can find many terms describing the manager, but in any case the essence of the character is to have a set of certain traits and competences, that the
CHARACTERISTICS AND COMPETENCES

Beata Anna Glinkowska 
CHARACTERISTICS AND COMPETENCES

Beata Anna Glinkowska classics of management understood as a set of technical, social and conceptual skills (Katz, 1955) and diagnostic skills (Griffin, 2004).

The concept of competence refers primarily to the actions of people and organizations. It is commonly said that a person is competent to perform a task or activity. According to T. Czapla, in the organization there is one set of competences that can be viewed from two perspectives: of the organization and of the employee. Both perspectives should complement one another (Czapla, 2011). Managerial competences „mean effectiveness of actions (...). They are necessary to perform in rofessional capacity and help in the management process. They make it possible to create a competitive advantage for organizations that are active today in a turbulent and uncertain environment" (Adamik and Bednarska-Wnuk, 2014). According to some researchers, managerial competences are the scope of mandates and authorization for actions and decisions for those who have the ability to bear responsibility and have conceptual, organizational, technical, administrative and interpersonal skills (Nogalski and Sniadecki, 1998). Having certain managerial skills, gives managers the ability to perform certain functions in relation to the resources of the organization: material and human. A. Sajkiewicz emphasizes that contemporary managerial competencies are identified with professional knowledge, skills in making the right decisions, cooperation and partnership, respect for ethics, and experience (Sajkiewicz, 2008). Being competent is the source of authority for managers.

Apart from conceptual, technical and social competences, the subject literature often indicates personal competences to be needed for the success of the organization. Some authors include objectivity in self-assesment, behavioral elasticity, communication skills, stress resistance, and tolerance for uncertainty (Schermerhorn, 2008). The essence and requirements of the position require managers to have specific political competences, especially in certain situations, or when other competences are at a lower level (Rakowska, 2007). B. Kaczmarek emphasizes that managerial competencies depend on the level of management „(...) the conceptual and diagnostic skills dominate at the highest level, while the technical skills play a minor role; on the middle level, both types of skills are more or less equally important; and for low-level managers the most important are technical skills, whereas the role of conceptual and diagnostic skills is small" (Kaczmarek, 2013). C. Levy-Leboyer believes that every manager should have the following competences (Levy-Leboyer, 1997):

- intellectual (strategic perspective, analysis and evaluation, planning and organization);

- interpersonal (people management, persuasiveness, decision-making, relationship sensitivity, verbal communication skills);

- adaptability (motives of adaptation, adaptability); 
- focus on results (energy and initiative, desire for success, entrepreneurial sense).

$\mathrm{R}$. Walkowiak is of the opinion that the following components build compe-

CHARACTERISTICS AND COMPETENCES

Beata Anna Glinkowska tencies (Walkowiak, 2004):

- knowledge (characterised by: dominance, inexhaustibility, simultaneity, nonlinearity);

- skills (behavior related to the task on hand, acquired through learning);

- experience ( the result of practicing, practice);

- personality traits (set of mental traits, system of attitudes, beliefs, motives, needs, openness, imagination, willingness to change);

- attitudes and behaviors (knowledge, emotions, readiness to act).

It is difficult to challenge any of the presented approaches. By analyzing them, one can conclude that a competent manager should have certain attributes to perform specific tasks, called explicitly competent actions. A manager's competence can be determined on the basis of the efficiency and effectiveness of the action he or she takes, both qualitatively and in relation to the manner of accomplishing the task.

\section{Profile of managerial competence by J. Penc from 2001}

In his work, J. Penc emphasized the universality of the model, despite it being called the Polish model. He noted that organizations operating in an international and global environment need to address the quality of human management (Penc, 2001), which was more and more often referred to as intellectual capital. He anticipated the growth of the initiative and the creativity of the staff, that would result in a new learning curve for their managers, so that the action was effective. His analyses were based, inter alia, on the works of P. Nieder (Nieder, 1998), K. Averdunk (Averdunk, 1996), M. Bratnicki (1988), J. Strużyna (Strużyna, 2000), D. N. Sull (Sull, 1999) and others (e.g. M. Hammer, J. Champ, G. Hammel). He pointed to the de-bureaucratization of the organization and the respect for the principles of creating an appropriate organizational structure.

M. Crozier also emphasized, not unlike J. Penc, the importance of adapting people to predetermined organizational and managerial goals in such a way as to minimize their development limitations (Crozier, 1993). This meant concentrating efforts on working with people and improving both the management methods and the character traits of managers. According to the researchers at the time, this focus was intended to reveal new opportunities as a result of unlocking the decks of creativity and potential in humans (Nizard, 1998).

R. M. Kanter (with whom J. Penc agreed) predicted that, in 2010, organizations will be shaped by six major changes that have a significant impact on people (Kanter, 1998):

- downsizing (layoffs, outsourcing to other organizations); 
Beata Anna Glinkowska
- a new organization (decentralizing the organization through delegation);

- diversity (resulting from different social and cultural groups, loss of gender relevance);

- expertise and contacts (new sources of power, loss of privileges, business contacts);

- projects (increased importance of team organizational culture, job satisfaction);

- professional value (reputation capital is more important than corporate capital).

All the above resulted in the necessity of authority associated with the position to give way to expertise and to perceive the manager as a leader. This was emphasized by J.A. Egli, who lists among key competencies in management: selecting and supporting employees, setting goals, communicating openly, increasing responsibility (Egli, 1996). J. Penc reffered to it simply as managerial effectiveness (Penc, 2001). P. F. This effectiveness, regardless of culture, was conditioned by the following managerial predispositions (Drucker, 1994):

- Awareness of one's own potential;

- Encouraging feedback;

- Desire to acquire knowledge;

- Integration: work - personal life;

- Respect for diversity.

J. Penc, seeing the need for changes in managerial competences, also agreed with T. Peters, for whom the so-called managers of tomorrow have to use the Liberation Management (Peters, 1992). He also agreed with C.K. Prahalad, for whom the manager of "tomorrow" should think systematically, be able to work in a multicultural setting, be ready to acquire knowledge continuously, have positive personality traits, and high standards of behavior (Prahalad, 1998).

Taking into account all of the above-mentioned existing research results, concepts, approaches and directions, J. Penc proposed the following profile of the Polish manager (Penc, 2001). J. Penc accepted 2001 as a starting point(thin line), making the probablist assumption for 2010 (thick line).

Through an analysis of the above data, a conclusion can be made that, according to J. Penc, towards the end of 2001, the most important features and competences of the Polish manager were: professional knowledge, traditional virtues (dilligence, punctuality, order), motivation skills, confidence, stress resistance, worldview, work experience abroad, as well as connections and networking. Less significance was given to factors such as general education, personality and charisma, courtesy and understanding, ability to listen, perseverance in pursuit of a goal, ability to anticipate, imagination and creativity, ability to mobilize, risk taking, field of study and knowledge of foreign languages. Openness, sense of obligation to inform and negotiation skills were considered of no value by J. Penc. 


\begin{tabular}{|c|c|c|c|}
\hline Characteristic & $\begin{array}{c}\text { High } \\
\text { importance }\end{array}$ & $\begin{array}{c}\text { Low } \\
\text { importance }\end{array}$ & $\begin{array}{c}\text { No } \\
\text { importance }\end{array}$ \\
\hline \multicolumn{4}{|l|}{ Education } \\
\hline \multicolumn{4}{|l|}{ Expertise } \\
\hline \multicolumn{4}{|c|}{ Personality, charisma } \\
\hline \multicolumn{4}{|c|}{ Traditional virtues (dilligence, punctuality, order) } \\
\hline \multicolumn{4}{|c|}{ Kindness, understanding } \\
\hline \multicolumn{4}{|c|}{ Opennes, sense of obligation to inform } \\
\hline \multicolumn{4}{|l|}{ Ability to motivate } \\
\hline \multicolumn{4}{|l|}{ Ability to listen } \\
\hline \multicolumn{4}{|l|}{ Confidence } \\
\hline \multicolumn{4}{|c|}{ Decision-making skills } \\
\hline \multicolumn{4}{|c|}{ Perseverance in goal pursuit } \\
\hline \multicolumn{4}{|l|}{ Ability to anticipate } \\
\hline \multicolumn{4}{|l|}{ Emotional balance } \\
\hline \multicolumn{4}{|l|}{ Stress resistance } \\
\hline \multicolumn{4}{|c|}{ Imagination, creativity, originality } \\
\hline \multicolumn{4}{|c|}{ Good physical and mental condition } \\
\hline \multicolumn{4}{|l|}{ Ability to mobilize } \\
\hline \multicolumn{4}{|l|}{ Negotiation skills } \\
\hline \multicolumn{4}{|l|}{ Risk taking } \\
\hline \multicolumn{4}{|c|}{ Professed worldview (relatively persistent view) } \\
\hline \multicolumn{4}{|l|}{ Field of study } \\
\hline \multicolumn{4}{|c|}{ Work experience abroad } \\
\hline \multicolumn{4}{|l|}{ Foreign languages } \\
\hline Connections & & & \\
\hline
\end{tabular}

Manager of the future (2010)

Manager in 2001

Figure 1.

Profile of a Polish manager by J. Penc (2001)

Source: elaboration based on (Penc, 2001). 
CHARACTERISTICS AND COMPETENCES

Beata Anna Glinkowska
For the manager of the future (2010) he foresaw the following as factors of low or no importance: professed worldview, expertise, traditional virtues (dilligence, punctuality, order), field of study, work experience abroad, connections and relationships. The remaining factors shaping the profile of the future manager have been predicted to be of great importance. And how does it look today, in 2017? The answer to this question can be found in the following section of this article.

\section{Profile of managerial competencies in 2017}

When confronting the results of the research described in the introduction of this paper (its background, purpose, subject and object), with the model proposed by J. Penc, the following conclusions were made, as shown in Figure 2. It bears reminding that the research has been carried out among modern managers (or specialists) of different levels of management and business owners who, indirectly (through intermediaries) or directly (directly with foreign companies on the Polish market or abroad) are managing a company based in Poland. Nowadays, there are more and more companies that are looking for opportunities to operate on foreign markets. Internationalization of business activity has become a fact, although Polish companies in this respect are not as advanced as in Western Europe or in the USA. Hence, the characteristics of the modern manager and manager of "tomorrow" (2020-2025), as an international manager, should be taken under more serious consideration.

What needs to be emphasized as well is the fact that the study was much broader and contained a cafeteria of more diverse characteristics and competencies defining the manager's profile. However, due to the assumption that the research was to be comparable with J. Penc's competence profile, the following table (Figure 2 ), showcases only factors that were included in the original model, showing the state of 2001 and assumptions for 2010 (Penc, 2001). For the remaining features and competences of the current manager (2017) and the manager of the future (2020-2025), the author will refer to in the final section of this paper.

The analysis of the data shown in Figure 2, based on own research (black line ), leeds to the assumption that in 2001, the direction of the development of the characteristics and competences of the manager of the future (not only for 2010, but also for 2017) has been properly defined. The importance of some characteristics has changed, but the degree of change is not high. Such characteristics as personality, charisma, courtesy, understanding, motivation, ability to listen, ability to anticipate, stress resistance, emotional balance, imagination, creativity, originality, risk taking, work experience abroad have gained importance in 2017 compared to 2010. The work experience abroad in confrontation with the type of subject accepted for this study seems to be astonishing. The increase of the importance of connections and relationships 


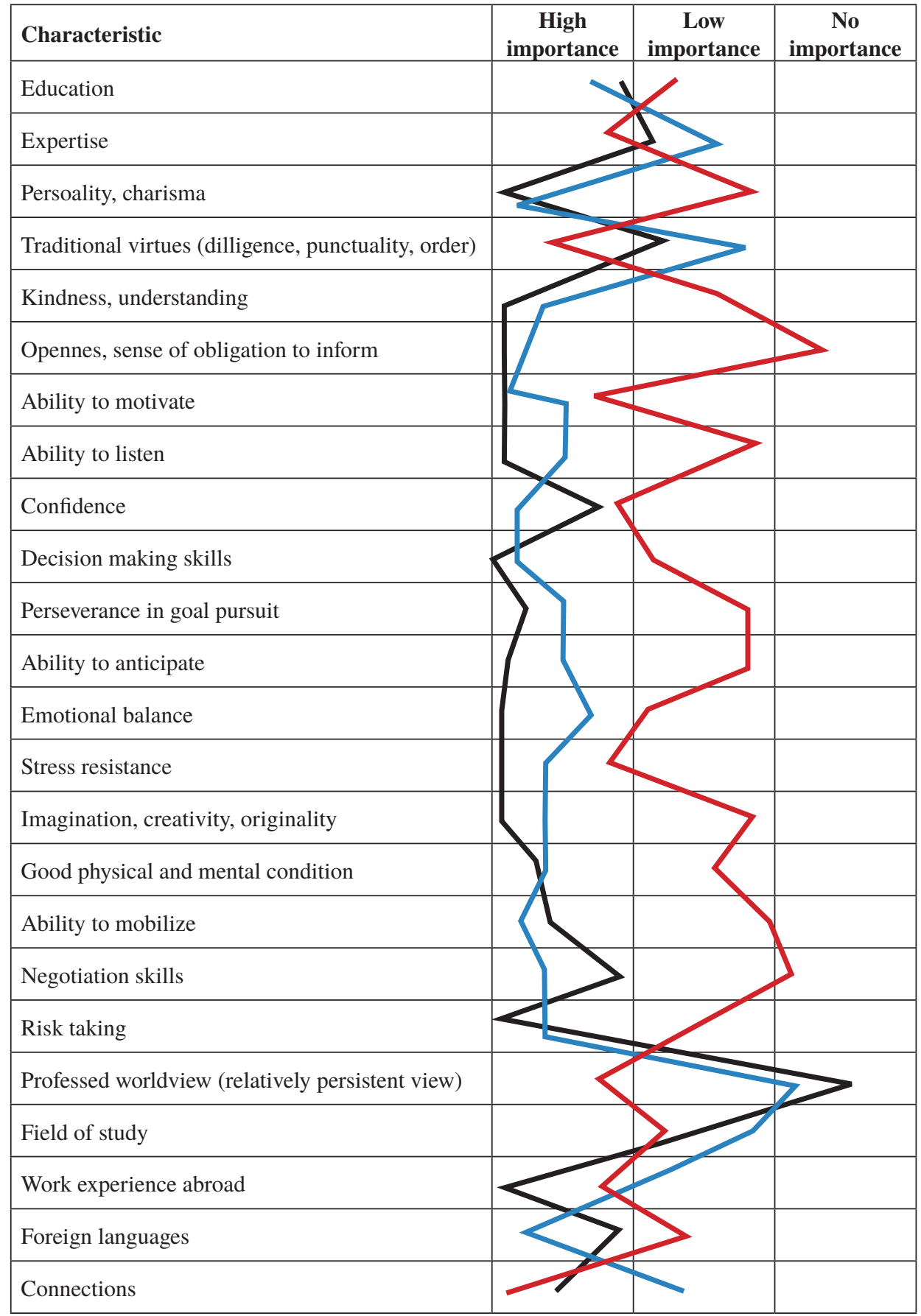

Manager - past (2010);

Manager - today (2017)
CHARACTERISTICS AND COMPETENCES

Beata Anna Glinkowska
Figure 2.

Profile of a contemporary Polish manager (2017)

Source: elaboration based on own research 
CHARACTERISTICS AND COMPETENCES

Beata Anna Glinkowska in the opinion of respondents is also surprising. A clear decrease, in terms of importance, can be observed for two characteristics: professed worldview, ability to negotiate and confidence. It is therefore safe to assume that the profile of the "manager of tomorrow" (not just the Polish "manager of tomorrow") will be evaluated based on his soft skills and personality characteristics, ie leadership, rather than technical competence. Thus the hypothesis of the study has been confirmed.

\section{Conclusions and recommendations}

The empirical research conducted by the author, based on a broader cafeteria of qualities and competences, additionally provided the results that a Polish manager in the future would be more of a leader than a manager and should have the highest qualifications and competences (aside from those mentioned above):

- ability to visualise and formulate goals,

- ability of conceptual thinking and acting,

- ability to communicate,

- support and motivation,

- ability to listen and draw conclusions,

- honesty, justice, ethics, morality, social responsibility,

- ability to work with and to create multicultural teams,

- enthusiasm and energy.

The least important competences, aside from those mentioned in figure 2 (less than $50 \%$ of the response frequency) are the following characteristics and competences:

- knowledge of state-of-the-art communication technologies,

- ability to control and detect errors.

In conclusion, there is an increasing demand for the so-called soft skills and the ability to create a vision, communicate, support, motivate. The area of ethics and morality of a modern manager poses as a new challenge, which gains more significance. It is to be expected that in the future the need will arise to seek the right proportions and the integration of activities that aim to ensure development and good economic results for the organization, not forgetting about respect for ethical and moral principles for all stakeholders. The ability to seek compromise solutions for often conflicting interests will be required from the manager-leader. Organizational attitude and behavior of managers are strongly conditioned by the influence of endogenous and exogenous factors, but the manager-leader in the future is supposed to have the ability to communicate but also to listen and draw conclusions. He or she is supposed to be a moral and socially responsible inspirer, capable of working in a multicultural environment. 
References

Adamik, A., Bednarska-Wnuk, I. (2014), "Luka kompetencyjna a kompetencje kierownicze w MSP”, Studia Ekonomiczne Regionu Łódzkiego, No. 13, pp. 63-77.

Averdunk, K. (1996), "Przedsiębiorstwo jako ucząca się organizacja", Zarządzanie na Świecie, No. 1, pp. 33-35.

Austen, A. (2010), "Efektywność przywództwa w organizacji publicznej”, Organizacja i zarzadzanie, Vol. 4 No. 12, pp. 25-42.

Bratnicki, M. (1988), Transformacja przedsiębiorstwa, Wydawnictwo Akademii Ekonomicznej, Katowice.

Crozier, M. (1993), Przedsiębiorstwo na podsłuchu. Jak uczyć się zarzqdzania postindustrialnego, Polskie Wydawnictwo Ekonomiczne, Warszawa.

Czapla, T. (2011), Modelowanie kompetencji pracowniczych w organizacji, Wydawnictwo Uniwersytetu Łódzkiego, Łódź.

Drucker, P.F. (1994), Menedżer skuteczny, Akademia Ekonomiczna w Krakowie, Kraków.

Egli, J.A. (1996), "Kluczowe umiejętności w kierowaniu ludźmi”, Zarządzanie na Świecie, No. 6, pp. 30-34.

Glinkowska, B., Kaczmarek, B. (2016a), Zarządzanie międzynarodowe i internacjonalizacja przedsiębiorstw. Teoria i praktyka, Wydawnictwo Uniwersytetu Łódzkiego, Łódź.

Glinkowska, B., Kaczmarek, B. (2016b), Zarzqdzanie międzynarodowe. Strategie i studia przypadków, Wydawnictwo Uniwersytetu Łódzkiego, Łódź.

Griffin, R. (2004), Podstawy zarządzania organizacjami, Wydawnictwo Naukowe PWN, Warszawa.

Kaczmarek, B. (2013), Współczesne wyzwania dla zarządzania przedsiębiorstwami, Wydawnictwo Dom Organizatora, Toruń.

Kanter, R.M. (1998), "Pozyskiwanie ludzi dla organizacji przyszłości”, in: Hesselbein, F., Goldsmith M., Beckhard, R. (Eds.), Organizacja przyszłości, Wydawnictwo Business Press, Warszawa, pp. 160-162.

Katz, R.L. (1955), "Skills of an Effective Administrator", Harvard Business Review, Vol. 52 No. 5, pp. 38-40.

Kubik, K. (2012), Menedżer w procesie zarzadzania zasobami ludzkimi, Wydawnictwo PTM, Warszawa.

Kuc, B.R. (2016), "Paradoksy przywództwa: Od szamana do showmana”, E-mentor, pp. 163-165.

Levy-Leboyer, C. (1997), Kierowanie kompetencjami. Bilans doświadczeń zawodowych, Wydawnictwo Poltext, Warszawa.

Nieder, P. (1998), “Zarządzanie przez zaufanie”, Zarządzanie na Świecie, No. 9, pp. 20-22.

Nizard, G. (1998), Metamorfozy przedsiębiorstwa. Zarządzanie w zmiennym otoczeniu organizacji, Wydawnictwo Naukowe PWN, Warszawa.

Nogalski, B., Śniadecki, J. (1998), Kształtowanie umiejętności menedżerskich, Wydawnictwo TNOiK, Bydgoszcz.

Penc, J. (2001), Kreowanie zachowań w organizacji, Agencja Wydawnicza Placet, Warszawa.
CHARACTERISTICS AND COMPETENCES

Beata Anna Glinkowska 
CHARACTERISTICS AND COMPETENCES

Beata Anna Glinkowska
Peters, T. (1992), Liberation Management. Necessary Disorganization for the Nanosecond Nineties, Alferd A. Knopf, New York.

Prahalad, C.K. (1998), Rola menedżerów nowej ery na konkurencyjnym rynku, in: Hesselbein, F., Goldsmith M., Beckhard, R. (Eds.), Organizacja przyszłości, Wydawnictwo Business Press, Warszawa, pp. 191-192.

Rakowska, A. (2007), Kompetencje menedżerskie kadry kierowniczej we wspótczesnych organizacjach, Wydawnictwo Uniwersytetu Marie Curie-Skłodowskiej, Lublin.

Sajkiewicz, A. (2008), Kompetencje menedżerów w organizacji uczącej się, Difin, Warszawa.

Schermerhorn, J.R. (2008), Zarzqdzanie. Kluczowe koncepcje, Polskie Wydawnictro Ekonomiczne, Warszawa.

Strużyna, J. (2000), "Wymiary kapitału ludzkiego firmy", in: Kożuch, B. (Ed.), Kształtowanie kapitału ludzkiego firmy, Wydawnictwo Uniwersytetu w Białymstoku, Białystok.

Sull, D.N. (1999), "Why Good Companies Go Bad", Harvard Business Review, Vol. 77 No. 4, pp. 1-12.

Walkowiak, R. (2004), Model kompetencji menedżerów organizacji samorzq̨dowych, Wydawnictwo Uniwersytetu Warmińsko-Mazurskiego w Olsztynie, Olsztyn. 